who in infancy had been medically treated for rickets. When she was $8 \frac{1}{2}$ years old there was a coxa vara on both sides, combined on the left side with mal. c. C.-L.-P. The patient had never limped nor shown any symptoms till after a trauma one year earlier. Immediately afterwards she had begun limping and complaining of pain in the left knee.

Mal. c. C.-L.-P. can appear in a previously completely normal joint, as Sinding-Larsen, among others, has maintained, ${ }^{5}$ and as one may also find examples of in my casuistic.

Frommé's hypothesis that "Spätrachit" is the cause of the disease is not generally applicable. This does not, however, exclude the disease being in some cases an expression of "tardive rachit." This, I think, to be the case with two patients of mine, described in my work (Cases 22 and 66), as well as with two later cases. All these four patients were boys whose disease had attacked both sides. All had suffered from rickets which had put its stamp on their entire habitus.

I suppose the chances are that in all four cases the cause of the disease was founded on a rachitic basis. This I think to be the case with three other bilateral cases examined by me (Cases $18,47,54)$. Taken all in all, I suppose that bilateral disease developing either spontaneously or after a trauma in patients with a history of rickets is to be considered as determined by rickets, and when the disease does not appear till four years afterwards, it is to be considered as a "tardive rachit."

Calot has lately, on a basis of 150 observations, ${ }^{6}$ denied the existence of any mal. c. C.-L.-P. in saying categorically, "La maladie de Perthes (ou Legg) n'existe pas. Les containes des cases cités sont autant de "subluxation congenitales larvées et meconnuées." The very fact that the disease as mentioned mostly appears in a previously quite normal hip disproves sufficiently Calot's theory. The subluxation which is not rare in the course of the disease is secondary, unless it depends on alterations of the acetabulum of a rachitic nature.

Lenormant, in $1913,{ }^{7}$ and later Delitala, ${ }^{8}$ maintained that the disease depends upon a dystrophia cong. The same can be said against this as against Calot's theory, 'but on the other side his hypothesis cannot be rejected when the symptoms of the disease have been present ever since the child began walking. Such a case is No. 57 in my material.

Though there are thus several causes of the disease all have this in common, that they bring forth a disturbance in the joint's state of nutrition. As in nearly all cases the clinical and $X$ ray picture is the same and the course of the disease is uniform, it is likely that the causal factors mentioned are only accidental and exciting, and the actual predisposing cause is to be sought in more fundamental circumstances. Note the development of the disease at a particular age, its predilection for one sex, its at times familiar appearance, and its alternation within the same family with other diseases of the hip (one can find mal. c. C.-L.P. on one side and luxat. c. cong. on the other in the same individual). I have thought the most fundamental cause of the disease to be disturbances of certain endocrine glands or of the interaction between them. One must in this connexion remember the relation of osteomalacia to the ovaries, particular forms of arthritis deformans to the thyroid gland, and Axhausen's interpretation of these and other diseases as "Knochendystrophie" brought about by alterations in the secretion of the intern glands. Lrven, in examining a skeleton of a cretin, found a pronounced mal c. C.-L.-P. on both sides, ${ }^{9}$ and Erkes has found the disease in a patient with a pronounced typus adiposogenitalis.-I am, Sir, yours faithfully,

HALFDAN SUNDT,

Medical Superintendent of Fredriksvern

Fredriksvern, Norway. Coast Hospital, Norway.

${ }^{5}$ Norsk Magazin for Lægevidenskapen, No. 4, 1915.

6 Journal des Praticiens, Jan. 22nd, 1921. La Presse Médicale.

8 American Jour. of Orthop. Surg, 1915

9 Deut. Zeitschr. f. Chir., Bd. ci.
WARMING ETHER VAPOUR FOR INHALATION.

To the Editor of THE LANCET.

SiR,--May I draw attention to what I consider a danger with regard to some intratracheal anæsthesia apparatus recently described in your columns ${ }^{1}$ viz., the method of heating the ether-laden air by an electric incandescent lamp? Dr. W. J. McCardie has described ${ }^{2}$ an accident caused, almost certainly. by a minute spark in the bulb fittings which fired the ether, and it seems not to have been a unique occurrence. The temperature required for the ignition of ether is considerably higher than for coalgas, but, once alight, the vapour burns fiercely, the flame licking up outlying streams. Mixed with a proper proportion of air it may explode with violence. Moreover, heating gases and vapours with the object of administering them warm is generally futile. Their specific heat is so extremely low that, while they can be heated with the utmost ease, passage through a foot or two of rubber tubing, even with moderate rapidity, will effectually reduce them to its own temperature, nor does the temperature of the tube become appreciably raised. For example, the temperature of air blown by a foot-bellows through 20 feet of copper tubing in hot water appeared to be $110^{\circ} \mathrm{F}$., while, blown only through a few fittings, equal to about 8 or 10 inches of the hot tubing, it was $108^{\circ} \mathrm{F}$., and many experiments gave consistent results. Again, where the temperature of a room was $62^{\circ} \mathrm{F}$. ether-laden air blown through a tube immersed in water at $152^{\circ} \mathrm{F}$., which heated it efficiently, and then through 18 inches of rubber tubing about 9/32 inch in diameter for five minutes, registered $68^{\circ} \mathrm{F}$., while five minutes after the hot water had been removed it registered $65^{\circ} \mathrm{F}$. showing, it would seem, that the temperature of the room largely controlled the result. There are fallacies in connexion with taking the temperature of gases in movement. They invalidate the reading of a thermometer placed in the space underneath a lint-covered Schimmelbusch frame, where it will act much as the wet bulb in a hygrometer.

Possibly a useful way of warming vapour for inhalation would be to pass it through a short length of rubber tubing-18 inches would sufficeplaced on the patient's chest, beneath the clothing. and thence by the shortest route to his nose and mouth.-I am, Sir, yours faithfully,

Nay 16th. Anæsthetist, Manchester Royal Infirmary.

\section{EARLY DIAGNOSIS IN DIPHTHERIA.}

To the Editor of THE LANCET.

SIR,-If in all cases of diphtheria antidiphtheritic serum could be administered sufficiently early, and in efficient dose, then the disease could be regarded as comparatively innocuous. This, I believe, is the steadily growing and considered opinion of those in the profession in a favourable position to judge And now if this statement of opinion is granted as correct, then the continued considerable death rate in this disease is a reproach. Ideally, serum ought to be administered at once on the first reasonable suspicion of diphtheria, then a swab should be taken from the throat. If the result of bacteriological examination of the latter is positive then valuable time in treatment has been gained, and if negative, the patient's condition has not been prejudiced. Too often it is found when the case arrives at the isolation hospital that serum has not been administered at all, or that valuable time in treatment has been lost by waiting on the result of bacteriological examination before administering serum. The important point to be noted here is that during this lost time toxins are rapidly becomin: fixed in the patient's nervous tissue, with irreparable

1 ThE LANCET, April 2nd, p. 704, and April 30th, p. 918.

Royal Soc. of Medicine, Section of Anesthetics, Mar, th, 1921 
damage to the prospects of subsequent treatment and consequently also to prognosis.

The following practical steps to give the all important earlier administration of serum suggest themselves to me:-

(1) Health vi-itors, under the M.O.H., should bo instructed how to take swaks and administer serum.

(ii) The practiıioner in attendance should serid, a telephone or otherwisa, immerliate notice to the Health Office of cases of sore throat, in which there exists a reaconable suspicion of the existence of diphtheritic infection, with a request that the health visitor be sent at oncr to administer an initial dose cf serum in such quantity as the practitioner may order.

(3) A swab could be taken by the health visitor at the same time, and the result of bacteriological examination awaited.

(1) Free access to fresh serum and swab outfit should be given to the practitioner at all times to provide for the following contingencies: $(\alpha)$ the practitioner wishing to administer the initial dose personally, or $(b)$ to allow of the practitioner giving it personally, where unnecessary delay would otherwise arise through the health offices being closed, as at night-time, week-ends, or public holidays.

It should, however, be noted that, not infrequently (and this especially applies to working-class areas), the delay in the application of serum treatment has arisen through parents not considering it necessary to seek early medical advice in cases of sore throat in their children, and this is especially dangerous in the presence in the district of diphtheria in epidemic form. Parents, and the public generally, might be made more alive to the sovereign virtue of serum administered early in diphtheria, and to the serious consequences to the patient that may arise through omission of such early administration. This could be done by educative propaganda, say by the public health authorities.

If this letter helps in any way the efforts to reduce a preventable mortality it will have accomplished its purpose.-I am, Sir, yours faithiully,

J. EwING ADAM, M.D., F.R.C.S. Edin., D.P.H.

May 23rd, 1921. Medical Superintendent, Mogden Isolation

To the Editor of THE LANCET.

Str,- The letter from Dr. Frederic Thomson in THE LANCET of May 21 st indicates the responsibilities of directors of bacteriological laboratories.

When I had charge of the bacteriological laboratory in the borough of Southend-on-Sea, in reporting on swabs submitted $I$ was in the habit of issuing a printed report of the result of examination, at the foot of which I warned the practitioner that a negative result did not necessarily mean that the case was not one of diphtheria. Another sentence emphasised the importance of giving antitoxin when diphtheria was suspected, without waiting for the bacteriological result.

The Norfolk County Council has recently started a County Iaboratory, and naturally I am adopting the same precautions in my reports.

I am, Sir, yours faithfully,

$$
\text { J. 'T. C. NASH. }
$$

The Shire House, Norwich, May 23rd, 1921.

$$
\text { THE WEANLING. }
$$

To the Editor of THE LANCET.

SIr,- The babies of the poor country Arabs in Upper Egypt have no intermediate stage. They receive a slab of coarse wholemeal bread while they are still on the breast, and when weaned many of them get little or no milk because of their parents' poverty. These children, fed chiefly on the real staff of life-water, raw fruits, and raw vegetable also with lentil soup, grow into fine men and women with good teeth and.powerful jaws. In fourteen years no case of appendicitis, no case of gastric ulcer, no case of cancer either of breast or stomach was seen at the hospital. Yet the Egyptian surgeons inform me that they see a fair number of cases of appendicitis amongst the children of the rich in Cairo. The country native if promoted to be the servant of a house in Cairo loses his good teeth, though I think that the large amount of raw fruit he still eats tends to prevent theix decay. The poor native takes his sugar only in the form of the fibrous cane or in other fruits. What I should like to know, Sir, is this: How many cases of appendicitis, gastric or duodenal ulcer, and cancer of the stomach arise in those favoured few of our population who have never suffered from dental caries? Surely the first thing is to concentrate on the prevention of dental caries; at any rate it is my firm belief that with the return of sound teeth the diseases abovementioned will almost disappear. I am, Sir, yours faithfully, II. F. NTCKOLLS DUNN.

Bath Club, Dover-street, W., May 13th, 1921.

\section{HELIOTHERAPY IN SURGICAT TUBERCULOSIS.}

\section{To the Editor of THE LANCET.}

SIR,--It is no exaggeration to state that heliotherapy is to-day, at least on the Continent, recognised as the treatment par excellence of surgical tuberculosis. The success of Rollier at Leysin and others on the Riviera testifies that the medical profession and the public at large are becoming more and more aware of the great ralue of a systematised sun cure. Thus no one need nowadays despair of ever bringing back to perfect health, and at times with absolute restoration to its primitive function, a chronically inflamed tuberculous joint. That eminently desperate condition, morbus coxæ, even if suppurating, and that no less discouraging affection, Pott's disease, when not too advanced, both vield to the all-powerful and healing effect of the sun. Again, chronic adenitis, whether the glands be enlarged singly or in groups, whether suppurating or not, can be and is always cured by heliotherapy.

As Rollier says, few cases of local tuberculosis are more susceptible to the treatment, and this without resorting to aspiratory methods. injection of antiseptic substances, and still less to excision. Thus a cure is obtained without reinfection, so constant after operative treatment, and without scars. On the Riviera, where we have treated a large number of cases by sun cure, we have further obtained excellent results in tuberculosis of the abdomen, in all manners of chronically inflamed conditions of bony surfaces, tuberculous or otherwise, in tuberculosis of the uro-genital tract, pleuro-pneumonia, neuritis, neuro-arthropathies, callous ulcers with varicose enlargement, staphylococcic infections, and in the convalescence from abdominal operations, especially those connected with the bowels. To sum up, heliotherapeutics not only shows itself particularly efficacious in all forms of local tuberculosis, when not too advanced, but is also the ideal form of treatment for a large variety of diseases where a general impairment of health has led to an imperfect action of the kidneys and of the skin, and where symptoms of chronic intoxication by toxins dominate the scene.-I am, Sir, yours faithfully,

Weymouth-street. G. A. Casalis de Pury.

\section{SURGICAL SHOCK.}

\section{To the Editor of THE LANCET.}

SIR,-In surgical shock, uncomplicated by severe hremorrhage, either external or internal, or by toxic substances capable of dilating capillaries, there appears to be an intense contraction of the whole vascular system, arteries, veins, and capillaries, as stated by Mr. John D. Malcolm. Granted the existence of a contracted vascular system, this becomes no longer capable of containing all the blood, and the volume of blood is reduced by migration of the blood-fluids from the vessels into the tissues, with the result that the blood in actual 